\title{
Resenha - Uma Contribuição à Educação e Pesquisa Contábil
}

Obra: SIQUEIRA, José Ricardo Maia de e PEREIRA, Wally Chan. Ensino e Pesquisa em Contabilidade. Rio de Janeiro: Freitas Bastos, 2006.

O livro reflete uma preocupação do Mestrado em Ciências Contábeis da UFRJ com a situação do ensino de Contabilidade no país. Existem relativamente poucos Mestres e Doutores em Contabilidade no Brasil e, por esta razão, um objetivo central do Mestrado em Ciências Contábeis da UFRJ é o aprimoramento e formação de Professores para o ensino médio e superior e de pesquisadores.

Esta meta requer um trabalho simultâneo de aperfeiçoamento dos conhecimentos técnicos dos alunos do Mestrado e de sua preparação para exercer o magistério e atividades de pesquisa. $\mathrm{O}$ livro em análise procura contribuir para o segundo objetivo, ao abordar questões relevantes sobre a educação e a pesquisa em Contabilidade.

Ao cumprir este objetivo, o livro é muito útil tanto para Professores de Contabilidade como para pessoas interessadas na carreira acadêmica, com destaquei para alunos de pósgraduação. Estes profissionais podem encontrar no livro informações valiosas sobre diferentes aspectos da educação superior e da pesquisa em Contabilidade.

De fato, uma das características marcantes do livro é a variedade de pontos de vista adotados e temas abordados. Quanto ao primeiro aspecto, note-se que o livro é escrito por vários autores, com formação e inserção diferenciada.

Os temas abordados pelo livro podem ser divididos em dois grupos principais. Quatro dos capítulos do livro discutem diferentes aspectos das práticas pedagógicas. Há uma preocupação com o excesso de aulas expositivas e a necessidade de adoção de técnicas alternativas de ensino. No capítulo intitulado "Estratégias de Ensino em Contabilidade, Por que Não?" se discute as vantagens e desvantagens de outros métodos, destacando os seguintes: estudos de caso, seminários, pesquisa técnico-científica em sala de aula e simulação empresarial.

O segundo grupo de capítulos debate diferentes aspectos da organização de programas de ensino superior em Contabilidade, com destaque para o ensino de pós-graduação. Um exemplo é o sétimo capítulo, onde é avaliada e discutida a inserção de disciplinas da área de estratégia nos cursos de pós-graduação em Ciências Contábeis. Esta questão é fundamental para a formação profissional em contabilidade pois, na ascensão profissional na carreira em organizações públicas e privadas, o contador progressivamente passa da execução de atividades técnicas para cargos de gestão, onde conhecimentos mais abrangentes sobre a operação da firma em geral e sua estratégia, em particular, são essenciais. Por isto, seria útil que os cursos de Mestrado e Doutorado em Ciências Contábeis proporcionassem aos seus alunos a oportunidade de apreender novos conhecimentos sobre administração, em geral, e estratégia, em particular.

Mas o levantamento empírico realizado pelos autores conclui que há pouca oferta de cursos de estratégia nos mestrados em Ciências Contábeis. O capítulo discute de forma detalhada as consequiências destes resultados.

Assim, o livro é muito útil para as pessoas que seguem ou pretendem seguir a atividade acadêmica no Brasil na área de contabilidade. Uma de suas maiores vantagens está no tratamento abrangente dado à questão do ensino e da organização do ensino em Ciências Contábeis, permitindo ao interessado um contato com um leque variado de questões e possibilidades. 
Sociedade, Contabilidade e Gestão, Rio de Janeiro, v. 2, n. 2, segundo semestre de 2007.

Victor Prochnik

Professor Associado

Universidade Federal do Rio de Janeiro

Faculdade de Administração e Ciências Contábeis

Mestrado em Ciências Contábeis

Av. Pasteur, 250 - Praia Vermelha

Rio de Janeiro - RJ

CEP: 22.290-240

victor@ie.ufrj.br 